\title{
Shewanella halifaxensis sp. nov., a novel obligately respiratory and denitrifying psychrophile
}

\author{
Jian-Shen Zhao, ${ }^{1}$ Dominic Manno, ${ }^{1}$ Cindy Leggiadro, ${ }^{2}$ David O'Neil ${ }^{2}$ \\ and Jalal Hawari ${ }^{1}$ \\ ${ }^{1}$ Biotechnology Research Institute, National Research Council of Canada, 6100 Royalmount \\ Avenue, Montreal, Quebec, Canada H4P 2R2 \\ ${ }^{2}$ Institute for Marine Biosciences, National Research Council of Canada, 1411 Oxford Street, \\ Halifax, Nova Scotia, Canada B3H $3 Z 1$
}

Correspondence

Jian-Shen Zhao

jian-shen.zhao@cnrc-nrc.gc.ca

\begin{abstract}
Indigenous bacteria found in the sediment of the Emerald Basin (depth of $215 \mathrm{~m}$, Atlantic Ocean) located offshore of Halifax Harbour (Nova Scotia, Canada) were previously found to be able to degrade the explosive compound hexahydro-1,3,5-trinitro-1,3,5-triazine (RDX). In the present study, a novel obligately respiratory, denitrifying and RDX-mineralizing bacterium, designated strain HAW-EB $4^{\top}$, was isolated from the marine sediment. This bacterium utilized peptone, yeast extract, Casamino acids, esters (Tweens 20, 40 and 80), sugars ( $N$-acetyl-D-glucosamine, ribose), several $\mathrm{C}_{2}$ and $\mathrm{C}_{3}$ acids (acetate, pyruvate, lactate, propionate) and amino acids (serine, proline) as sole carbon and energy sources. Aerobically grown cells (in marine broth 2216 at $10{ }^{\circ} \mathrm{C}$ ) contained $\mathrm{C}_{14: 0}(6 \%)$, iso- $\mathrm{C}_{15: 0}(12 \%), \mathrm{C}_{16: 0}(20 \%), \mathrm{C}_{16: 1} \omega 7(37 \%), \mathrm{C}_{18: 1} \omega 7(7 \%)$ and $\mathrm{C}_{20: 5} \omega 3(7 \%)$ as major membrane fatty acids, and Q7 (28.1\%) and MK-7 (60.9\%) as dominant respiratory quinones, consistent with deep-sea species of Shewanella. The novel bacterium had a DNA G +C content of $45 \mathrm{~mol} \%$ and showed similarity to Shewanella species in terms of 16S rRNA and gyrB gene sequences (93-99 and 67.3-88.4\% similarity, respectively), with Shewanella pealeana being the most closely related species. Genomic DNA-DNA hybridization between strain HAW-EB4 ${ }^{\top}$ and S. pealeana revealed a level of relatedness of $17.9 \%$, lower than the $70 \%$ species cut-off value, indicating that strain $\mathrm{HAW}-\mathrm{EB} 4^{\top}\left(=\mathrm{NCIMB} 14093^{\top}=\mathrm{DSM}\right.$ $\left.17350^{\top}\right)$ is the type strain of a novel species of Shewanella, for which the name Shewanella halifaxensis sp. nov. is proposed.
\end{abstract}

The genus Shewanella was first described by MacDonell \& Colwell (1985) to accommodate Gram-negative, oxidasepositive, rod-shaped, aquatic and marine bacteria with genomic DNA G + C contents of 39-53 mol\%. Twenty-nine species of Shewanella were recognized at the time of writing (Bozal et al., 2002; Brettar \& Hofle, 2002; Ivanova et al., 2001, 2003a, b, 2004a, b, c; Leonardo et al., 1999; Skerratt et al., 2002; Satomi et al., 2003; Toffin et al., 2004; Venkateswaran et al., 1999; Xu et al., 2005; Yoon et al., 2004a, b). Deep-sea Shewanella species such as Shewanella violacea, S. benthica, S. woodyi, S. hanedai and S. marinintestina require $\mathrm{Na}^{+}$and low temperature for growth and produce polyunsaturated fatty acids (Bowman et al., 1997;

Published online ahead of print on 23 September 2005 as DOI 10.1099/ijs.0.63829-0.

Abbreviations: RDX, hexahydro-1,3,5-trinitro-1,3,5-triazine; TMAO, trimethylamine $\mathrm{N}$-oxide.

The GenBank/EMBL/DDBJ accession numbers for the 16S rRNA and gyrB gene sequences of strain HAW-EB4 ${ }^{\top}$ are AY579751 and AY842131.
Deming et al., 1984; Jensen et al., 1980; Kato et al., 1998; Kato \& Nogi, 2001; MacDonell \& Colwell, 1985; Makemson et al., 1997; Nogi et al., 1998; Russell \& Nichols, 1999; Satomi et al., 2003). Mesophilic and non- $\mathrm{Na}^{+}$-requiring Shewanella species such as Shewanella algae, S. amazonensis, S. decolorationis, S. japonica, S. oneidensis and S. putrefaciens are usually found in coastal regions, estuaries and/or nonmarine environments (Ivanova et al., 2001; Long \& Hammer, 1941; Nozue et al., 1992; Simidu et al., 1990; Venkateswaran et al., 1998b, 1999; Xu et al., 2005; Zhao et al., 2005). Some species of Shewanella are known for their potential to degrade organic pollutants (Petrovskis et al., 1994; Semple \& Westlake, 1987; Xu et al., 2005; Zhao et al., 2004b). The strain described herein, designated HAW-EB4 ${ }^{\mathrm{T}}$, was initially isolated as an effective RDX (hexahydro-1,3,5-trinitro1,3,5-triazine)-mineralizing bacterium from marine sediment obtained from a munitions-dumping area located in Emerald Basin, Atlantic Ocean, offshore Halifax Harbour, Novo Scotia, Canada (Zhao et al., 2004b). In the present study, we found that this bacterium represented a novel obligately respiratory and denitrifying species of Shewanella. 
As we reported previously (Zhao et al., 2004b), strain HAW$\mathrm{EB}^{\mathrm{T}}$ was a psychrophilic bacterium (optimum growth at $10^{\circ} \mathrm{C}$ ) and grew well aerobically on Brewer anaerobic agar (Becton Dickinson) supplemented with sea salts ( $4 \%$; Sigma), producing a slightly dark orange or pinkish pigmentation similar to other species of Shewanella (Venkateswaran et al., 1999). Cells harvested after 3 days aerobic incubation in marine broth 2216 (Difco) at $10^{\circ} \mathrm{C}$ (spun at 180 r.p.m.) were used for transmission (TEM; Hitachi H7500) or scanning (SEM; Hitachi S3000N) electron microscopic image analyses. For TEM, cells were negatively stained with phosphotungstic acid $(0.5 \%$, w/v; $\mathrm{pH}$ 6.0) as described by Bozal et al. (2002) and Beveridge et al. (1994). For SEM, cells were collected on poly-L-lysinecoated coverslips, treated with glutaraldehyde/formaldehyde, tannic acid and osmium tetroxide as described by Prevost et al. (1992), dried using hexamethyldisilazane and sputter-coated with gold/palladium. Like those of most Shewanella species, cells of strain HAW-EB4 ${ }^{\mathrm{T}}$ were Gramnegative, straight or slightly curved rods. Electron microscopic image analyses showed that cells were $1 \cdot 5-3 \mu \mathrm{m}$ long with a diameter ranging from 0.55 to $0.65 \mu \mathrm{m}$ (Fig. 1a) and had a single polar flagellum (Fig. 1b).

To determine the phylogenetic affiliation of strain HAW$\mathrm{EB} 4^{\mathrm{T}}$, we purified its genomic DNA $(1-5 \mathrm{mg})$ using the
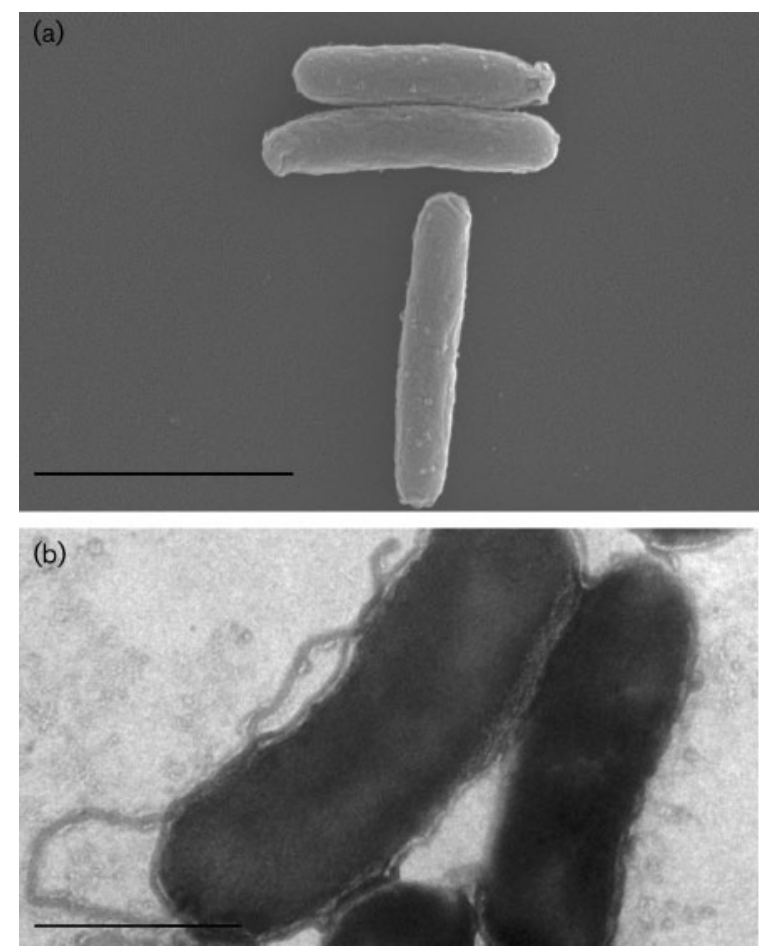

Fig. 1. Micrographs of cells of strain $H A W-E B 4^{T}$ : (a) scanning electron micrograph of cells; (b) transmission electron micrograph of a negatively stained cell showing a single polar flagellum. Bars, $2 \cdot 5 \mu \mathrm{m}$ (a) and $1 \mu \mathrm{m}$ (b).
Marmur method (Johnson, 1994), and amplified its 16S rRNA and gyrB (coding for the $\beta$-unit of DNA topoisomerase II) genes using universal primers (Yamamoto \& Harayama, 1995; Venkateswaran et al., 1998a) and standard molecular protocols (Sambrook \& Russell, 2001). The partial 16S rRNA (1293 bases) and gyrB (938 bases) genes were subsequently sequenced and compared with published sequences using BLAST (NCBI GenBank; http://www. ncbi.nlm.nih.gov/). The gene sequences of strain HAW$\mathrm{EB} 4^{\mathrm{T}}$ and those of closely related species were aligned using CLUSTAL_X (version 1.81). The neighbour-joining method included in the MEGA2 package (Kumar et al., 2001), based on pairwise nucleotide distances with the Kimura twoparameter correction, was used to construct the phylogenetic tree. The number of bootstrap repetitions was 4000.

The genomic DNA G $+\mathrm{C}$ content of strain HAW-EB4 ${ }^{\mathrm{T}}$, determined using $\mathrm{UV}$ absorbance $\left(A_{269} / A_{280}\right)$ at $\mathrm{pH} 3.0$ and its thermal melting profile $\left(T_{\mathrm{m}}\right)$ (Johnson, 1985a), was found to be $45 \mathrm{~mol} \%$, consistent with reported values for other species of Shewanella (39-53 mol\%). Phylogenetic analyses of the 16S rRNA gene sequence clearly showed that strain HAW-EB4 ${ }^{\mathrm{T}}$ belonged to the genus Shewanella (93-99\% similarity to recognized Shewanella species); it was related most closely to Shewanella pealeana (99\%), found in Atlantic squid accessory nidamental gland (Leonardo et al., 1999), S. marinintestina, Shewanella schlegeliana and Shewanella sairae, which are marine intestinal species (98.6-99\%) (Satomi et al., 2003), and Shewanella gelidimarina, found in Antarctic congelation ice (97.9\%) (Bowman et al., 1997) (Fig. 2). Among the above related species, $S$. pealeana was found to be phylogenetically most closely related to HAW-EB4 ${ }^{\mathrm{T}}$ ( $99 \%$ similarity, bootstrap value of $99 \%$ ) (Fig. 2). In comparing the gyrB gene sequences, strain HAW-EB4 ${ }^{\mathrm{T}}$ showed $67 \cdot 3-88 \cdot 4 \%$ similarities to species of Shewanella, and was most similar to $S$. pealeana (Fig. 3). However, gyrB gene sequence similarity between HAW-EB4 ${ }^{\mathrm{T}}$ and S. pealeana was $88 \cdot 4 \%$, lower than the $90 \%$ species cut-off value recommended for Shewanella species (Venkateswaran et al., 1999), suggesting that the two bacteria belong to different species.

Strain HAW-EB4 ${ }^{\mathrm{T}}$ was also found to be phylogenetically distant from another Halifax sediment Shewanella isolate, Shewanella sediminis HAW-EB3 ${ }^{\mathrm{T}}$ (Zhao et al., 2005), with low $16 \mathrm{~S}$ rRNA (96.4\%; Fig. 2) and gyrB (83.3\%; Fig. 3) gene sequence similarities.

We conducted genomic DNA-DNA hybridization between strain HAW-EB4 ${ }^{\mathrm{T}}$ and S. pealeana using the spectrophotometric method as described by Johnson (1985b) and Bowman et al. (1998). Strain HAW-EB4 ${ }^{\mathrm{T}}$ and S. pealeana had a level of genomic DNA relatedness of $17 \cdot 9 \%$, which was much lower than the $70 \%$ species cut-off value accepted for bacteria (Wayne et al., 1987; Stackebrandt \& Goebel, 1994; Gillis et al., 2001), demonstrating that strain HAW$\mathrm{EB} 4^{\mathrm{T}}$ represents a novel species of Shewanella. 


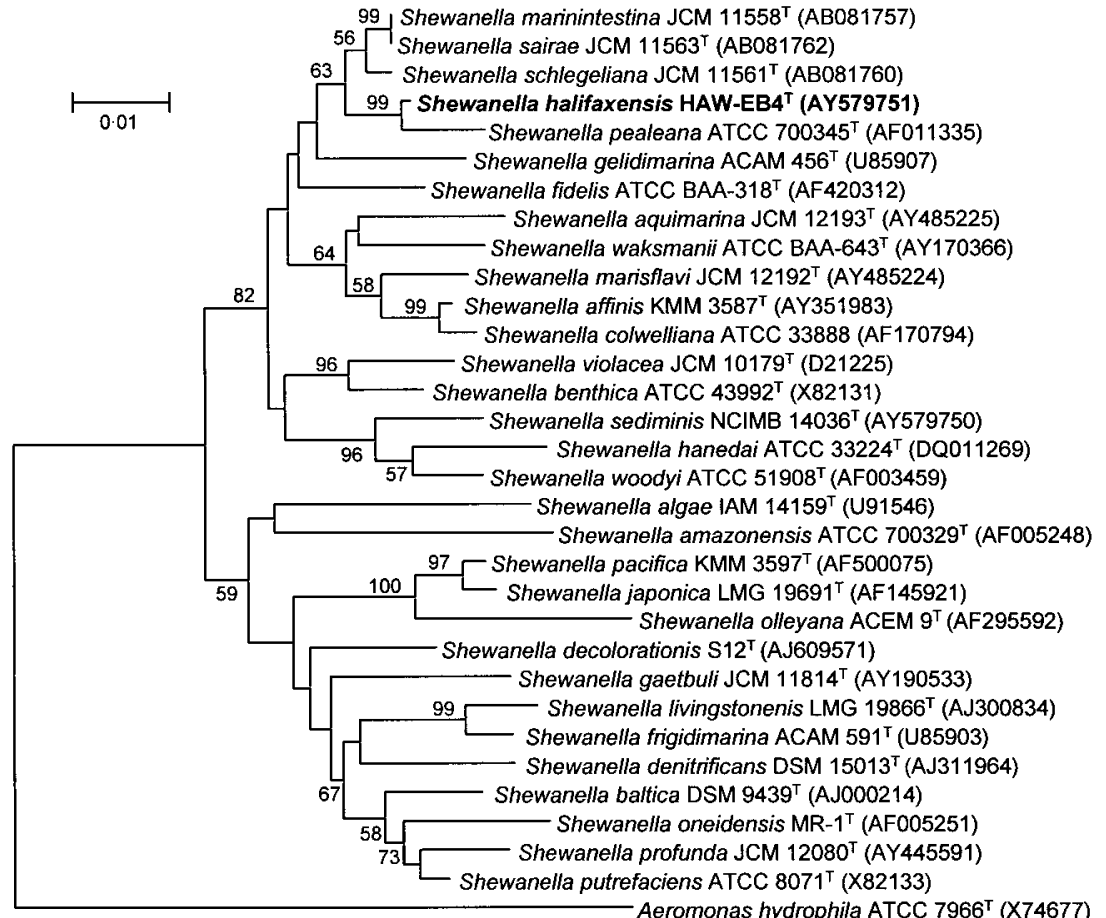

Fig. 2. Phylogenetic tree based on $16 \mathrm{~S}$ rRNA gene sequences of type strains of Shewanella species and strain HAW-EB4 ${ }^{\top}$. The phylogenetic tree was generated based on pairwise nucleotide distances with Kimura twoparameter correction using the neighbourjoining method (pairwise deletion) included in the MEGA2 software package (Kumar et al., 2001). Numbers beside the nodes are bootstrap values (percentage of 4000 replications). Bar, $1 \%$ sequence divergence.
To compare the chemotaxonomic properties of strain HAW$\mathrm{EB} 4^{\mathrm{T}}$ with those of recognized species of Shewanella, we characterized the respiratory quinone and membrane fatty acid composition of strain HAW-EB4 ${ }^{\mathrm{T}}$ (grown aerobically in marine broth 2216 at $10^{\circ} \mathrm{C}$ ) using previously described chromatographic methods (Collins, 1985, 1994; Nishijima et al., 1997; Akagawa-Matsushita et al., 1992; Bowman, 2001; Fay \& Richli, 1991; Zhao et al., 2005). Briefly, strain HAW$\mathrm{EB} 4^{\mathrm{T}}$ produced mainly straight-chain fatty acids such as palmitic $\left(\mathrm{C}_{16: 0}, 20 \%\right)$, myristic $\left(\mathrm{C}_{14: 0}, 6 \%\right)$ and palmitoleic $\left(\mathrm{C}_{16: 1} \omega 7,37 \%\right)$ acid, branched fatty acids (iso- $\mathrm{C}_{13: 0}, 3 \%$; iso- $\left.\mathrm{C}_{15: 0}, 12 \%\right)$ and polyunsaturated eicosapentaenoic acid $\left[\mathrm{C}_{20: 5} \omega 3(\mathrm{EPA}), 7 \%\right]$, similar to related species of Shewanella (Table 1). The major respiratory quinones of strain HAW-EB4 ${ }^{\mathrm{T}}$ were ubiquinones $(\mathrm{Q} 7,28 \cdot 1 \%)$ and menaquinones (MK-7, 60.9\%), consistent with Shewanella species (Akagawa-Matsushita et al., 1992; Venkateswaran et al., 1999; Bozal et al., 2002; Zhao et al., 2005).
$\mathrm{NaCl}$ tolerance was tested on Brewer anaerobic agar that contained $0 \cdot 5,1 \cdot 5,2 \cdot 0,2 \cdot 5,3 \cdot 0,4 \cdot 0,6 \cdot 0$ or $8 \cdot 0 \% \mathrm{NaCl}$ (aerobic growth conditions) using a previously described protocol (Zhao et al., 2005). Growth in the absence of $\mathrm{Na}^{+}$ was tested in a $\mathrm{Na}^{+}$-free agar that contained $0.3 \%$ Bacto beef extract (Difco) and 0.5\% Bacto peptone (Difco). Strain HAW-EB4 ${ }^{\mathrm{T}}$ required $\mathrm{Na}^{+}$for growth and was slightly halophilic, with growth at $0 \cdot 5-4 \% \mathrm{NaCl}$. However, strain HAW-EB4 ${ }^{\mathrm{T}}$ appeared to have a lower tolerance to $\mathrm{NaCl}$ (optimum growth at $2 \% \mathrm{NaCl}$ ) than S. pealeana $(3 \%)$.

We also identified the electron acceptors of strain HAW$\mathrm{EB} 4^{\mathrm{T}}$ and compared them with those of recognized Shewanella species. Reduction of the following potential electron acceptors by strain HAW-EB4 ${ }^{\mathrm{T}}$ was tested in anaerobic jars on Brewer anaerobic agar supplemented with $2 \% \mathrm{NaCl}$ and one of the following substrates: $\mathrm{MnO}_{2}(40 \mathrm{mM})$, ferric citrate $(40 \mathrm{mM})$, amorphous iron oxide $(\mathrm{FeOOH}, 40 \mathrm{mM})$

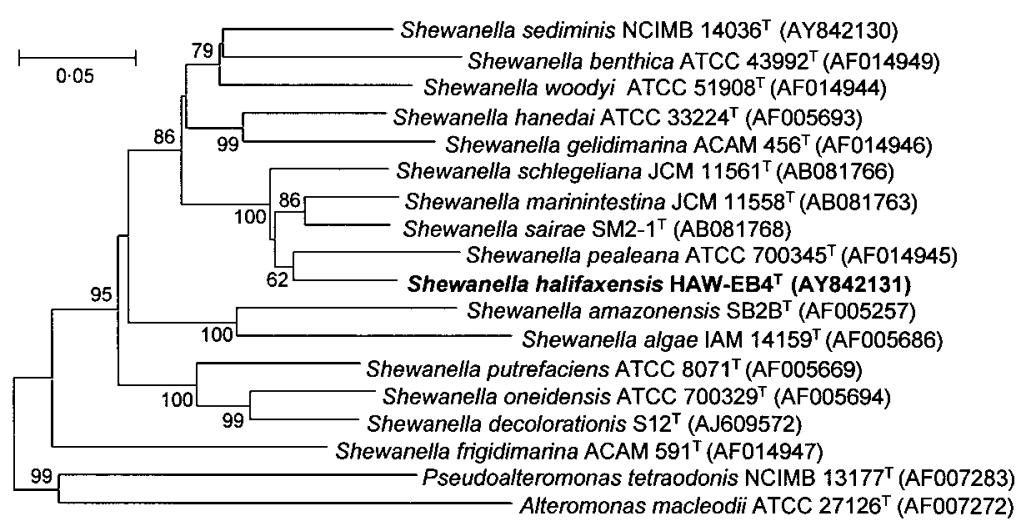

Fig. 3. Phylogenetic tree based on gyrB gene sequences of Shewanella species and strain $\mathrm{HAW}-\mathrm{EB} 4^{\top}$. The phylogenetic tree was generated based on pairwise nucleotide distances with Kimura two-parameter correction using the neighbour-joining method (pairwise deletion) included in the MEGA2 software package (Kumar et al., 2001). Numbers beside nodes are bootstrap values (percentage of 4000 replications; values below $50 \%$ not shown). Bar, $5 \%$ sequence divergence. 
Table 1. Fatty acid composition (percentages of total) of strain HAW-EB4 ${ }^{\top}$ and related Shewanella species

Taxa: 1, HAW-EB4 ${ }^{\mathrm{T}}$; 2, S. pealeana; 3, S. gelidimarina; 4, S. schlegeliana; 5, S. marinintestina; 6, S. sairae. -, Not detected; ND, no data. Data for strain HAW-EB4 ${ }^{\mathrm{T}}$ from this study; data for reference species taken from Bowman et al. (1997), Leonardo et al. (1999) and Satomi et al. (2003).

\begin{tabular}{|lrccccc|}
\hline Fatty acid & $\mathbf{1}$ & $\mathbf{2}$ & $\mathbf{3}$ & $\mathbf{4}$ & $\mathbf{5}$ & $\mathbf{6}$ \\
\hline $\mathrm{C}_{12: 0}$ & - & $0 \cdot 2-4$ & $0 \cdot 3-0 \cdot 7$ & $1 \cdot 1$ & $0 \cdot 3$ & $0 \cdot 5$ \\
iso- $\mathrm{C}_{13: 0}$ & 3 & $2 \cdot 6-13 \cdot 8$ & $5 \cdot 4-15 \cdot 8$ & $2 \cdot 8$ & $2 \cdot 8$ & $3 \cdot 4$ \\
$\mathrm{C}_{13: 0}$ & - & $0 \cdot 9-1 \cdot 4$ & $0 \cdot 1-1 \cdot 3$ & - & - & $1 \cdot 9$ \\
$\mathrm{C}_{14: 0}$ & 6 & $2 \cdot 6-5 \cdot 6$ & $3 \cdot 8-5 \cdot 2$ & $4 \cdot 2$ & $4 \cdot 4$ & $5 \cdot 0$ \\
$\mathrm{C}_{14: 1}$ & 1 & - & $0 \cdot 1-0 \cdot 8$ & $\mathrm{ND}$ & $\mathrm{ND}$ & $\mathrm{ND}$ \\
iso- $\mathrm{C}_{15: 0}$ & 12 & $8 \cdot 4-16$ & $8 \cdot 3-13 \cdot 2$ & $6 \cdot 4$ & $9 \cdot 2$ & 14 \\
anteiso-C $15: 0$ & 1 & $1 \cdot 2$ & - & $0 \cdot 7$ & $0 \cdot 1$ & $0 \cdot 2$ \\
$\mathrm{C}_{15: 0}$ & 1 & $1-2 \cdot 5$ & $1 \cdot 6-6 \cdot 7$ & $0 \cdot 1$ & $0 \cdot 6$ & $0 \cdot 3$ \\
$\mathrm{C}_{16: 0}$ & 20 & $18 \cdot 6-25$ & $6 \cdot 4-13 \cdot 9$ & $22 \cdot 7$ & 22 & 18 \\
$\mathrm{C}_{16: 1} \omega 9$ & 1 & $0 \cdot 9$ & $0-0 \cdot 7$ & - & - & - \\
$\mathrm{C}_{16: 1} \omega 7$ & 37 & $19 \cdot 4$ & $27 \cdot 4-37$ & $26 \cdot 1$ & $26 \cdot 1$ & $28 \cdot 1$ \\
$\mathrm{C}_{17: 0}$ & - & $0 \cdot 7-2$ & $0 \cdot 4-0 \cdot 7$ & - & $0 \cdot 6$ & $0 \cdot 1$ \\
$\mathrm{C}_{17: 1}$ & - & $1-1 \cdot 2$ & $2 \cdot 7-5 \cdot 1$ & $0 \cdot 5$ & $1 \cdot 0$ & $0 \cdot 8$ \\
$\mathrm{C}_{18: 0}$ & 2 & $3-4 \cdot 1$ & $0 \cdot 1-0 \cdot 3$ & $1 \cdot 2$ & $3 \cdot 1$ & $1 \cdot 0$ \\
$\mathrm{C}_{18: 1} \omega 9$ & - & $2 \cdot 2$ & $0 \cdot 3-0 \cdot 9$ & $3 \cdot 3$ & $2 \cdot 1$ & - \\
$\mathrm{C}_{18: 1} \omega 7$ & 7 & $4-6 \cdot 3$ & $1 \cdot 0-8 \cdot 4$ & $6 \cdot 5$ & $6 \cdot 9$ & $9 \cdot 8$ \\
$\mathrm{C}_{20: 4} \omega 3$ & 1 & $1 \cdot 6$ & $0 \cdot 3-0 \cdot 8$ & $2 \cdot 2$ & $1 \cdot 1$ & $0 \cdot 7$ \\
$\mathrm{C}_{20: 5} \omega 3$ & 7 & $19 \cdot 1$ & $11 \cdot 7-16$ & $18 \cdot 6$ & $17 \cdot 5$ & $15 \cdot 2$ \\
\hline
\end{tabular}

or elemental sulfur $(40 \mathrm{mM})$. Anaerobic respiration on trimethylamine $N$-oxide (TMAO) $(10 \mathrm{mM})$, nitrate $(20 \mathrm{mM})$ or nitrite $(5 \mathrm{mM})$ as an electron acceptor $(0 \cdot 1 \%$ Casamino acids as carbon and energy sources) was tested in sea salts mineral medium $(5 \mathrm{ml}$ in $20 \mathrm{ml}$ sealed serum bottles, initial biomass of $\left.0.07 \mathrm{OD}_{600}\right)$ under anaerobic conditions (the medium was made anoxic by degassing under vacuum and charging the headspace with argon, and with no reducing agents added). Clear zones around colonies were used to indicate iron(III), manganese(IV) and sulfur reduction (Myers \& Nealson, 1988). Enhanced bacterial growth in the presence of electron acceptors (compared with that in their absence) was used as an indicator for dissimilatory reduction of nitrate, nitrite and TMAO. Bacterial growth on agar was estimated by multiplying the mean area of colonies and total number of colony-forming units (Zhao et al., 2005). Similar to S. pealeana ATCC $700345^{\mathrm{T}}$ (Leonardo et al., 1999), strain HAW-EB4 ${ }^{\mathrm{T}}$ was a respiratory bacterium that did not grow by fermentation but grew $\left(0 \cdot 1 \%\right.$ Casamino acids, $6-16$ days, 10 or $\left.21^{\circ} \mathrm{C}\right)$ by respiring on oxygen, nitrate, nitrite or TMAO, with a final biomass increase of $0 \cdot 12-0 \cdot 6 \mathrm{OD}_{600}$. Strain HAW-EB4 ${ }^{\mathrm{T}}$ reduced $\mathrm{MnO}_{2}$ as was the case with $S$. pealeana, but did not reduce two other electron acceptors of S. pealeana, iron(III) and elemental sulfur (Table 2). Strain HAW-EB4 ${ }^{\mathrm{T}}$ reduced nitrate and nitrite to nitrous oxide (Casamino acids as carbon source), confirming its identity as a denitrifying bacterium probably involved in denitrification in the Halifax harbour sediment.

Using previously described protocols (Bowman, 2001; Zhao et al., 2005) and marine broth 2216 as a basal medium, we characterized strain HAW-EB4 ${ }^{\mathrm{T}}$ for spore formation, acid production from sugars (in Leifson modified O-F medium; Smibert \& Krieg, 1994), $\mathrm{H}_{2} \mathrm{~S}$ formation from thiosulfate ( $1 \%$ ) and hydrolysis of DNA (in BBL DNA agar plus $4 \%$ sea salts), casein (skimmed milk, $50 \%$ ), gelatin (1\%), Tweens $20(1 \%), 40(1 \%)$ and $80(1 \%)$, olive oil (1\%), lecithin $(5 \%$ egg yolk), pure chitin $(0 \cdot 3 \%)$, alginate $(1 \%)$ and starch $(1 \%)$. Additional enzyme activities and substrate metabolisms were tested by using API Rapid 20E and ID32A (bioMérieux) test kits $\left(10\right.$ and $37^{\circ} \mathrm{C}$ ) and GN2 microplates (Biolog; cell biomass of $0.9 \mathrm{OD}_{600}$ suspended in sea-salts medium for 7 days at $10^{\circ} \mathrm{C}$ ). Utilization of carbon substrates $(0 \cdot 1 \%)$ by strain HAW-EB4 ${ }^{\mathrm{T}}$ and S. pealeana ATCC $700345^{\mathrm{T}}$ (purchased from the American Type Culture Collection) was tested aerobically at both $10^{\circ} \mathrm{C}$ (optimum growth of HAW-EB4 $4^{\mathrm{T}}$ ) and $21{ }^{\circ} \mathrm{C}$ (optimum growth of $S$. pealeana) in basic marine salts medium $(\mathrm{pH} 7 \cdot 0,0 \cdot 1 \%$ $\mathrm{NH}_{4} \mathrm{Cl}$ ) in the presence or absence of $0.02 \%$ yeast extract or $0.001 \%$ choline chloride. Bacterial growth $\left(\mathrm{OD}_{600}\right)$ was monitored every 3-6 days over 1 month (initial biomass of $\left.0.07 \mathrm{OD}_{600}\right)$. All phenotypic tests were run in triplicate.

Cluster analyses of phenotypic properties (enzyme activities, growth substrates, salt and temperature tolerance) of strain HAW-EB4 $4^{\mathrm{T}}$ and recognized species of Shewanella using the method of Zhao et al. (2005) also indicated that strain HAW-EB4 ${ }^{\mathrm{T}}$ was similar to deep-sea species of Shewanella. Like S. pealeana (Leonardo et al., 1999), strain HAW-EB4 ${ }^{\mathrm{T}}$ grew better in the presence of choline chloride (peptone, Casamino acids or yeast extract as carbon source; 1000$1300 \%$ increase in $\left.\mathrm{OD}_{600}\right)$ than in its absence $(600-900 \%$ increase in $\left.\mathrm{OD}_{600}\right)\left(10^{\circ} \mathrm{C}, 16\right.$ days). However, strain HAW$\mathrm{EB} 4{ }^{\mathrm{T}}$ differed from S. pealeana (Table 2) and three other known marine fish or scallop intestinal Shewanella species, S. marinintestina, S. schlegeliana and S. sairae, on activities of some enzymes and utilization of several carbon sources (Satomi et al., 2003). For example, strain HAW-EB4 ${ }^{\mathrm{T}}$ produced much less biomass $\left(15-150 \%\right.$ increase in $\mathrm{OD}_{600}$ ) than S. pealeana (150-700\% increase in $\mathrm{OD}_{600}$ ) at both 10 and $21{ }^{\circ} \mathrm{C}$ when growing on single compounds as sole carbon sources (Table 2). Yeast extract appeared to improve utilization of several carbon sources by strain HAW-EB4 ${ }^{\mathrm{T}}$ (Table 2).

Finally, strain HAW-EB4 ${ }^{\mathrm{T}}$ was able to utilize the biodegradation product of RDX, formate, as sole carbon and energy source for growth (at $21^{\circ} \mathrm{C}$ ) (Table 2), suggesting that RDX can be utilized by strain HAW-EB4 $4^{\mathrm{T}}$ during potential occurrence of in-situ natural attenuation of RDX at the contaminated site (Zhao et al., 2004a, b).

The phenotypic, chemotaxonomic and genetic data presented here demonstrate that strain $\mathrm{HAW}-\mathrm{EB} 4^{\mathrm{T}}$ is a distinct marine bacterium, representing a novel species of 
Table 2. Phenotypic properties of strain HAW-EB4 ${ }^{\top}$ and related species of Shewanella

Taxa: 1, HAW-EB4 ${ }^{\mathrm{T}}$; 2, S. pealeana; 3, S. gelidimarina; 4, S. schlegeliana; 5, S. marinintestina; 6, S. sairae. All data for strain HAW-EB4 ${ }^{\mathrm{T}}$ and growth substrate data for S. pealeana were from the present study. Other data were from Bowman et al. (1997), Satomi et al. (2003), Leonardo et al. (1999) and Kato \& Nogi (2001). All listed species grew on $N$-acetyl-D-glucosamine, ribose and valerate as sole carbon sources. + , Positive; $\mathrm{W}+$, weakly positive; -, negative; ND, no data. Values in parentheses for HAW-EB4 ${ }^{\mathrm{T}}$ and $S$. pealeana indicate the increase in biomass $\left(\mathrm{OD}_{600}\right.$; as a percentage relative to initial value of 0.07$)$ after $6-16$ days incubation in basic sea-salts medium at 10 or $21^{\circ} \mathrm{C}$.

\begin{tabular}{|c|c|c|c|c|c|c|}
\hline Characteristic & 1 & 2 & 3 & 4 & 5 & 6 \\
\hline Habitat & $\begin{array}{l}\text { Atlantic } \\
\text { sediment }\end{array}$ & $\begin{array}{c}\text { Atlantic } \\
\text { squid accessory } \\
\text { nidamental gland }\end{array}$ & $\begin{array}{l}\text { Antarctica } \\
\text { sea ice }\end{array}$ & $\begin{array}{c}\text { Black porgy } \\
\text { intestine }\end{array}$ & $\begin{array}{l}\text { Squid } \\
\text { intestine }\end{array}$ & $\begin{array}{c}\text { Pacific saury } \\
\text { intestine }\end{array}$ \\
\hline Pigmentation & Orange/pink & Slightly pink & Tan & Ivory & Ivory & Ivory \\
\hline $\mathrm{Fe}(\mathrm{III})$ reduction & - & + & + & ND & ND & ND \\
\hline Growth at $30^{\circ} \mathrm{C}$ & - & + & - & + & - & - \\
\hline Growth at $6 \% \mathrm{NaCl}$ & - & - & + & - & - & - \\
\hline Gelatinase & + & - & + & + & + & + \\
\hline Caseinase & - & ND & + & ND & + & + \\
\hline Chitinase & + & - & + & - & - & - \\
\hline Butyrate & $-(<15)$ & $+(50-150)$ & + & - & - & - \\
\hline Leucine & $-(<15)$ & $+(50-150)$ & - & - & + & - \\
\hline Lactate & $+^{\star}(50-150)$ & $+(>300)$ & + & - & - & - \\
\hline Galactose & $-(<15)$ & $\mathrm{W}+(15-50)$ & - & - & - & - \\
\hline
\end{tabular}

${ }^{\star}$ Yeast extract enhanced growth.

Shewanella, for which the name Shewanella halifaxensis sp. nov. is proposed.

\section{Description of Shewanella halifaxensis sp. nov.}

Shewanella halifaxensis (ha.li.fax.en'sis. N.L. fem. adj. halifaxensis from Halifax, Nova Scotia, a harbour city near the sediment sampling site, Emerald Basin, where the type strain was isolated).

Cells are Gram-negative, non-spore-forming, straight or slightly curved rods generally $2-3 \mu \mathrm{m}$ long and $0 \cdot 55-$ $0.65 \mu \mathrm{m}$ in diameter. Cells $6 \mu \mathrm{m}$ long also occur. Motile by a single polar flagellum. Biomass is slightly dark yellow and non-bioluminescent. Psychrophilic growth at temperatures of $4-25^{\circ} \mathrm{C}$ (optimum at $10{ }^{\circ} \mathrm{C}$ ). No growth at $30^{\circ} \mathrm{C}$. $\mathrm{Na}^{+}-$ requiring and slightly halophilic $(0 \cdot 5-4 \% \mathrm{NaCl}$; optimum at $2 \%$ ). Growth at $4 \%$ but not at $6 \% \mathrm{NaCl} . \mathrm{MnO}_{2}$, nitrate, nitrite, TMAO, thiosulfate and RDX are reduced. No reduction of $\mathrm{Fe}^{3+}$ (iron oxide or ferric citrate) or elemental sulfur. Strong production of $\mathrm{H}_{2} \mathrm{~S}$ from thiosulfate. Anaerobic growth by reducing nitrate (to $\mathrm{N}_{2} \mathrm{O}$ ), nitrite or TMAO, but not by fermentation. Positive for catalase, oxidase, nitroreductase, chitinase, DNase, gelatinase, urease, arginine dihydrolase, ornithine decarboxylase, lysine decarboxylase, glutamic acid decarboxylase, $N$-acetyl- $\beta$-D-glucosaminidase, $\beta$-galactosidase, $\beta$-galactosidase-6-phosphate, alkaline phosphatase, leucine arylamidase and alanine arylamidase; weakly positive for hydrolysis of Tweens 20, 40 and 80, proline arylamidase and arginine arylamidase; negative for caseinase, alginase, amylase, $\alpha$-galactosidase, $\alpha$-glucosidase, $\beta$-glucosidase, $\alpha$-arabinosidase, $\beta$-glucuronidase, histidine arylamidase, serine arylamidase, phenylalanine arylamidase, pyroglutamic acid arylamidase, tyrosine arylamidase, glycylarylamidase, leucine glycine arylamidase, $\alpha$-fucosidase and glutamyl glutamic acid arylamidase. On GN2 microplate $\left(10^{\circ} \mathrm{C}, 7\right.$ days $)$, positive for metabolism of $N$-acetyl-Dglucosamine, $\alpha$-D-glucose, methylpyruvate, DL-lactic acid, L-alanine, L-alanyl glycine, glycyl L-aspartic acid, glycyl Lglutamic acid, L-serine, inosine, uridine and thymidine; weakly positive for Tweens 40 and 80 , acetic acid, $\beta$-hydroxybutyric acid, $\alpha$-ketobutyric acid, L-leucine and L-threonine; negative for $\alpha$-cyclodextrin, dextrin, glycogen, $N$-acetyl-D-galactosamine, adonitol, L-arabinose, D-arabitol, D-cellobiose, i-erythritol, D-fructose, D-fucose, D-galactose, gentiobiose, myo-inositol, $\alpha$-D-lactose, lactulose, maltose, Dmannitol, D-mannose, D-melibiose, methyl $\beta$-D-glucoside, D-psicose, D-raffinose, L-rhamnose, D-sorbitol, sucrose, 
D-trehalose, turanose, xylitol, succinic acid monomethyl ester, cis-aconitic acid, citric acid, formic acid, D-galactonic acid lactone, D-galacturonic acid, D-gluconic acid, Dglucosaminic acid, D-glucuronic acid, $\alpha$ - or $\gamma$-hydroxybutyric acid, $p$-hydroxyphenylacetic acid, itaconic acid, $\alpha$ ketoglutaric acid, $\alpha$-ketovaleric acid, malonic acid, propionic acid, quinic acid, D-saccharic acid, sebacic acid, succinic acid, bromosuccinic acid, succinamic acid, glucuronamide, L-alaninamide, D-alanine, L-asparagine, L-aspartic acid, Lglutamic acid, L-histidine, hydroxy-L-proline, L-ornithine, L-phenylalanine, L-proline, L-pyroglutamic acid, D-serine, DL-carnitine, $\gamma$-aminobutyric acid, urocanic acid, phenylethylamine, 2-aminoethanol, 2,3-butanediol, glycerol, DL- $\alpha$-glycerol phosphate, $\alpha$-D-glucose 1-phosphate and Dglucose 6-phosphate. Weak aerobic acid formation from $\mathrm{N}$-acetyl-D-glucosamine and glucose. No anaerobic acid formation from $\mathrm{N}$-acetyl-D-glucosamine, fructose, sucrose, galactose, lactose, mannose or glucose. Peptone, yeast extract, Casamino acid, Tweens (20, 40 and 80 ), propionate, pyruvate, serine and proline are sole carbon and energy sources for growth. $N$-Acetyl-D-glucosamine, ribose, lactate, acetate, valerate, glutamate, formate and glycine are weak growth substrates. Alanine, threonine, leucine, butyrate and glucose are poorly utilized. Succinate, citrate, malate and fumarate are not utilized. Choline and yeast extract are not required but improve growth on certain substrates. Fatty acids iso- $\mathrm{C}_{13: 0}(3 \%), \mathrm{C}_{14: 0}(6 \%), \mathrm{C}_{14: 1}(1 \%)$, anteiso$\mathrm{C}_{15: 0}(1 \%), \mathrm{C}_{15: 0}(1 \%)$, iso-C $15: 0(12 \%), \mathrm{C}_{16: 0}(20 \%)$, $\mathrm{C}_{16: 1} \omega 7(37 \%), \mathrm{C}_{16: 1} \omega 9(1 \%), \mathrm{C}_{18: 0}(2 \%), \mathrm{C}_{18: 1} \omega 7(7 \%)$, $\mathrm{C}_{20: 5} \omega 3(7 \%)$ and $\mathrm{C}_{20: 4} \omega 3(1 \%)$ are produced. Quinone composition is Q7 $(28 \cdot 1 \%)$, Q8 $(4 \cdot 0 \%)$, MK-7 $(60 \cdot 9 \%)$ and MMK-7 (6.9\%). The DNA G $+\mathrm{C}$ content is $45 \mathrm{~mol} \%$.

The type strain is HAW-EB4 $4^{\mathrm{T}}\left(=\mathrm{NCIMB} 14093^{\mathrm{T}}=\mathrm{DSM}\right.$ $\left.17350^{\mathrm{T}}\right)$, isolated from marine sediment.

\section{Acknowledgements}

Financial support from the Office of Naval Research (ONR), US Navy (Award N000140310269), is gratefully acknowledged. We thank Sonia Thiboutot, Guy Ampleman, D. Faucher (Defense Research and Development Canada, Valcartier, Quebec, Canada) and K. Penny (Canadian Navy) for sampling sediment. Technical support from Chantale Beaulieu, Louise Paquet, Annamaria Halasz and Carl Groom is also acknowledged.

\section{References}

Akagawa-Matsushita, M., Itoh, T., Katayama, Y., Kuraishi, H. \& Yamasato, K. (1992). Isoprenoid quinone composition of some marine Alteromonas, Marinomonas, Deleya, Pseudomonas and Shewanella species. J Gen Microbiol 138, 2275-2281.

Beveridge, T., Popkin, T. J. \& Cole, R. M. (1994). Electron microscopy. In Methods for General and Molecular Bacteriology, pp. 42-71. Edited by P. Gerhardt, R. G. E. Murray, W. A. Wood \& N. R. Krieg. Washington, DC: American Society for Microbiology.

Bowman, J. P. (2001). Methods for psychrophilic bacteria. Methods Microbiol 30, 591-615.

Bowman, J. P., McCammon, S. A., Nichols, D. S., Skerratt, J. H., Rea, S. M., Nichols, P. D. \& McMeekin, T. A. (1997). Shewanella gelidimarina sp. nov. and Shewanella frigidimarina sp. nov., novel Antarctic species with the ability to produce eicosapentaenoic acid $(20: 5 \omega 3)$ and grow anaerobically by dissimilatory $\mathrm{Fe}(\mathrm{III})$ reduction. Int J Syst Bacteriol 47, 1040-1047.

Bowman, J. P., McCammon, S. A., Lewis, T., Skerratt, J. H., Nichols, D. S. \& McMeekin, T. A. (1998). Psychroflexus torquis gen. nov., sp. nov., a psychrophilic species from Antarctic sea ice, and reclassification of Flavobacterium gondwanense (Dobson et al. 1993) as Psychroflexus gondwanense gen. nov., comb. nov. Microbiology 144, 1601-1609.

Bozal, N., Montes, M. J., Tudela, E., Jimenez, F. \& Guinea, J. (2002). Shewanella frigidimarina and Shewanella livingstonensis sp. nov. isolated from Antarctic coastal areas. Int J Syst Evol Microbiol 52, 195-205.

Brettar, R. C. \& Hofle, M. G. (2002). Shewanella denitrificans sp. nov., a vigorously denitrifying bacterium isolated from the oxic-anoxic interface of the Gotland Deep in the central Baltic Sea. Int J Syst Evol Microbiol 52, 2211-2217.

Collins, M. D. (1985). Analysis of isoprenoid quinones. Methods Microbiol 18, 325-366.

Collins, M. D. (1994). Isoprenoid quinones. In Chemical Methods in Prokaryotic Systematics, pp. 265-309. Edited by M. Goodfellow \& A. G. O'Donnell. Chichester: Wiley.

Deming, J. W., Hada, H., Colwell, R. R., Luehrsen, K. R. \& Fox, G. E. (1984). The ribonucleotide sequence of $5 S$ rRNA from two strains of deep-sea barophilic bacteria. J Gen Microbiol 130, 1911-1920.

Fay, L. \& Richli, U. (1991). Location of double bonds in polyunsaturated fatty acids by gas chromatography-mass spectrometry after 4,4-dimethyloxazoline derivatization. J Chromatogr 541, 89-98.

Gillis, M., Vandamme, P., De Vos, P., Swings, J. \& Kersters, K. (2001). Polyphasic taxonomy. In Bergey's Manual of Systematic Bacteriology, 2nd edn, vol. 1, pp. 43-48. Edited by D. R. Boone \& R. W. Castenholz. New York: Springer.

Ivanova, E. P., Sawabe, T., Gorshkova, N. M., Svetashev, V. I., Mikhailov, V. V., Nicolau, D. V. \& Christen, R. (2001). Shewanella japonica sp. nov. Int J Syst Evol Microbiol 51, 1027-1033.

Ivanova, E. P., Nedashkovskaya, O. I., Zhukova, N. V., Nicolau, D. V., Christen, R. \& Mikhailov, V. V. (2003a). Shewanella waksmanii sp. nov., isolated from a sipuncula (Phascolosoma japonicum). Int J Syst Evol Microbiol 53, 1471-1477.

Ivanova, P. E., Sawabe, T., Hayashi, K., Gorshkova, N. M., Zhukova, N. V., Nedashkovskaya, N. V., Mikhailov, O. I., Nicolau, V. V. \& Christen, R. (2003b). Shewanella fidelis sp. nov., isolated from sediments and sea water. Int J Syst Evol Microbiol 53, 577-582.

Ivanova, E. P., Nedashkovskaya, O. I., Sawabe, T., Zhukova, N. V., Frolova, G. M., Nicolau, D. V., Mikhailov, V. V. \& Bowman, J. P. (2004a). Shewanella affinis sp. nov., isolated from marine invertebrates. Int J Syst Evol Microbiol 54, 1089-1093.

Ivanova, E. P., Gorshkova, N. M., Bowman, J. P., Lysenko, A. M., Zhukova, N. V., Sergeev, A. F., Mikhailov, V. V. \& Nicolau, D. V. (2004b). Shewanella pacifica sp. nov., a polyunsaturated fatty acidproducing bacterium isolated from sea water. Int J Syst Evol Microbiol 54, 1083-1087.

Ivanova, E. P., Flavier, S. \& Christen, R. (2004c). Phylogenetic relationships among marine Alteromonas-like proteobacteria: emended description of the family Alteromonadaceae and proposal of Pseudoalteromonadaceae fam. nov., Colwelliaceae fam. nov., Shewanellaceae fam. nov., Moritellaceae fam. nov., Ferrimonadaceae fam. nov., Idiomarinaceae fam. nov. and Psychromonadaceae fam. nov. Int J Syst Evol Microbiol 54, 1773-1788.

Jensen, M. J., Tebo, B. M., Baumann, P., Mandel, M. \& Nealson, K. H. (1980). Characterization of Alteromonas hanedai (sp. nov.), a 
non-fermentative luminous species of marine origin. Curr Microbiol 3, 311-315.

Johnson, J. L. (1985a). Determination of DNA base composition. Methods Microbiol 18, 23-24.

Johnson, J. L. (1985b). DNA reassociation and RNA hybridisation of bacterial nucleic acids. Methods Microbiol 18, 33-74.

Johnson, J. L. (1994). Similarity analysis of DNAs. In Methods for General and Molecular Bacteriology, pp. 655-682. Edited by P. Gerhardt, R. G. E. Murray, W. A. Wood \& N. R. Krieg. Washington, DC: American Society for Microbiology.

Kato, C. \& Nogi, Y. (2001). Correlation between phylogenetic structure and function: examples from deep-sea Shewanella. FEMS Microbiol Ecol 35, 223-230.

Kato, C., Li, L., Nogi, Y., Nakamura, Y., Tamaoka, J. \& Horikoshi, K. (1998). Extremely barophilic bacteria isolated from the Mariana Trench, Challenger Deep, at a depth of 11,000 meters. Appl Environ Microbiol 64, 1510-1513.

Kumar, S., Tamura, K., Jakobsen, I.-B. \& Nei, M. (2001). MEGA2: molecular evolutionary genetics analysis software. Bioinformatics 17, 1244-1245.

Leonardo, M. R., Moser, D. P., Barbieri, E., Brantner, C. A., MacGregor, B. J., Paster, B. J., Stackebrandt, E. \& Nealson, K. H. (1999). Shewanella pealeana sp. nov., a member of the microbial community associated with the accessory nidamental gland of the squid Loligo pealei. Int J Syst Bacteriol 49, 1341-1351.

Long, H. F. \& Hammer, B. W. (1941). Classification of organisms important in dairy products. III. Pseudomonas putrefaciens. Iowa Agric Exp Stn Bull 285, 176-195.

MacDonell, M. T. \& Colwell, R. R. (1985). Phylogeny of the Vibrionaceae, and recommendation for two new genera, Listonella and Shewanella. Syst Appl Microbiol 6, 171-182.

Makemson, J. C., Fulayfil, N. R., Landry, W., Van Ert, L. M., Wimpee, C. F., Widder, E. A. \& Case, J. F. (1997). Shewanella woodyi sp. nov., an exclusively respiratory luminous bacterium isolated from the Alboran Sea. Int J Syst Bacteriol 47, 1034-1039.

Myers, C. R. \& Nealson, K. H. (1988). Bacterial manganese reduction and growth with manganese oxide as the sole electron acceptor. Science 240, 1319-1321.

Nishijima, M., Araki-Sakai, M. \& Sano, H. (1997). Identification of isoprenoid quinones by frit-FAB liquid chromatography-mass spectrometry for the chemotaxonomy of microorganisms. J Microbiol Methods 28, 113-122.

Nogi, Y., Kato, C. \& Horikoshi, K. (1998). Taxonomic studies of deep-sea barophilic Shewanella strains and description of Shewanella violacea sp. nov. Arch Microbiol 170, 331-338.

Nozue, H., Hayashi, T., Hashimoto, Y., Ezaki, T., Hamasaki, K., Ohwada, K. \& Terawaki, Y. (1992). Isolation and characterization of Shewanella alga from human clinical specimens and emendation of the description of S. alga Simidu et al., 1990, 335. Int J Syst Bacteriol 42, 628-634.

Petrovskis, E. A., Vogel, T. M. \& Adriaens, P. (1994). Effects of electron acceptors and donors on transformation of tetrachloromethane by Shewanella putrefaciens MR-1. FEMS Microbiol Lett 121, 357-364.

Prevost, M. C., Lesourd, M., Arpin, M., Vernel, F., Mounier, J., Hellio, R. \& Sansonetti, P. J. (1992). Unipolar reorganization of F-actin layer at bacterial division and bundling of actin filaments by plastin correlate with movement of Shigella flexneri within HeLa cells. Infect Immun 60, 4088-4099.

Russell, N. J. \& Nichols, D. S. (1999). Polyunsaturated fatty acids in marine bacteria - a dogma rewritten. Microbiology 145, 767-779.
Sambrook, J. \& Russell, D. W. (2001). Molecular Cloning: a Laboratory Manual, 3rd edn. Cold Spring Harbor, NY: Cold Spring Harbor Laboratory.

Satomi, M., Oikawa, H. \& Yano, Y. (2003). Shewanella marinintestina sp. nov., Shewanella schlegeliana sp. nov. and Shewanella sairae sp. nov., novel eicosapentaenoic-acid-producing marine bacteria isolated from sea-animal intestines. Int J Syst Evol Microbiol 53, 491-499.

Semple, K. M. \& Westlake, D. W. S. (1987). Characterization of iron reducing Alteromonas putrefaciens strains from oil field fluids. Can J Microbiol 35, 925-931.

Simidu, U., Kita-Tsukamoto, K., Yasumoto, T. \& Yotsu, M. (1990). Taxonomy of four marine bacterial strains that produce tetrodotoxin. Int J Syst Bacteriol 40, 331-336.

Skerratt, J. H., Bowman, J. P. \& Nichols, P. D. (2002). Shewanella olleyana sp. nov., a marine species isolated from a temperate estuary which produces high levels of polyunsaturated fatty acids. Int J Syst Evol Microbiol 52, 2101-2106.

Smibert, R. M. \& Krieg, N. R. (1994). Phenotypic characterization. In Methods for General and Molecular Bacteriology, pp. 607-654. Edited by P. Gerhardt, R. G. E. Murray, W. A. Wood \& N. R. Krieg. Washington, DC: American Society for Microbiology.

Stackebrandt, E. \& Goebel, B. M. (1994). Taxonomic note: a place for DNA-DNA reassociation and $16 \mathrm{~S}$ rRNA sequence analysis in the present species definition in bacteriology. Int J Syst Bacteriol 44, 846-849.

Toffin, L., Bidault, A., Pignet, P., Tindall, B. J., Slobodkin, A., Kato, C. \& Prieur, D. (2004). Shewanella profunda sp. nov., isolated from deep marine sediment of the Nankai Trough. Int J Syst Evol Microbiol 54, 1943-1949.

Venkateswaran, K., Dohmoto, N. \& Harayama, S. (1998a). Cloning and nucleotide sequence of the gyrB gene of Vibrio parahaemolyticus and its application in detection of this pathogen in shrimp. Appl Environ Microbiol 64, 681-687.

Venkateswaran, K., Dollhopf, M. E., Aller, R., Stackebrandt, E. \& Nealson, K. H. (1998b). Shewanella amazonensis sp. nov., a novel metal-reducing facultative anaerobe from Amazonian shelf muds. Int J Syst Bacteriol 48, 965-972.

Venkateswaran, K., Moser, D. P., Dollhopf, M. E. \& 10 other authors (1999). Polyphasic taxonomy of the genus Shewanella and description of Shewanella oneidensis sp. nov. Int J Syst Bacteriol 49, 705-724.

Wayne, L. G., Brenner, D. J., Colwell, R. R. \& 9 other authors (1987). Report of the ad hoc committee on reconciliation of approaches to bacterial systematics. Int J Syst Bacteriol 37, 463-464.

Xu, M., Guo, J., Cen, Y., Zhong, X., Cao, W. \& Sun, G. (2005). Shewanella decolorationis sp. nov., a dye-decolorizing bacterium isolated from activated sludge of a waste-water treatment plant. Int J Syst Evol Microbiol 55, 363-368.

Yamamoto, S. \& Harayama, S. (1995). PCR amplification and direct sequencing of gyrB genes with universal primers and their application to the detection and taxonomic analysis of Pseudomonas putida strains. Appl Environ Microbiol 61, 1104-1109.

Yoon, J.-H., Kang, K.-H., Oh, T.-K. \& Park, Y.-H. (2004a). Shewanella gaetbuli sp. nov., a slight halophile isolated from a tidal flat in Korea. Int J Syst Evol Microbiol 54, 487-491.

Yoon, J. H., Yeo, S. H., Kim, I. G. \& Oh, T. K. (2004b). Shewanella marisflavi sp. nov. and Shewanella aquimarina sp. nov., slightly halophilic organisms isolated from sea water of the Yellow Sea in Korea. Int J Syst Evol Microbiol 54, 2347-2352.

Zhao, J.-S., Greer, C. W., Thiboutot, S., Ampleman, G. \& Hawari, J. (2004a). Biodegradation of nitramine explosives hexahydro1,3,5-trinitro-1,3,5-triazine and octahydro-1,3,5,7-tetranitro-1,3,5,7tetrazocine in cold marine sediment under anaerobic and oligotrophic conditions. Can J Microbiol 50, 91-96. 
Zhao, J.-S., Spain, J., Thiboutot, S., Ampleman, G., Greer, C. \& Hawari, J. (2004b). Phylogeny of cyclic nitramine-degrading psychrophilic bacteria in marine sediment and their potential role in the natural attenuation of explosives. FEMS Microbiol Ecol 49, 349-357.
Zhao, J.-S., Manno, D., Beaulieu, C., Paquet, L. \& Hawari, J. (2005). Shewanella sediminis sp. nov., a novel $\mathrm{Na}^{+}$-requiring and hexahydro1,3,5-trinitro-1,3,5-triazine-degrading bacterium from marine sediment. Int J Syst Evol Microbiol 55, 1511-1520. 